\title{
Basic science: (November 2007)
}

1. Alexe G, Dalgin GS, Scanfeld D, Tamayo P, Mesirov JP, DeLisi C, Harris L, Barnard N, Martel M, Levine AJ, Ganesan S, Bhanot G. High expression of lymphocyte-associated genes in node-negative HER2 + breast cancers correlates with lower recurrence rates. Cancer Res 2007; 67: 10669-10676.

2. Assender JW, Gee JMW, Lewis I, Ellis IO, Robertson JFR, Nicholson RI. Protein kinase C isoform expression as a predictor of disease outcome on endocrine therapy in breast cancer. J Clin Pathol 2007; 60: 1216-1221.

3. Braunstein S, Karpisheva K, Pola C, Goldberg $\mathrm{J}$, Hochman T, Yee H, Cangiarella J, Arju R, Formenti SC, Schneider RJ. A hypoxia-controlled cap-dependent to cap-independent translation switch in breast cancer. Mol Cell 2007; 28: 501-512.

4. Chlebowski RT, Anderson GL, Lane DS, Aragaki AK, Rohan T, Yasmeen S, Sarto G, Rosenberg CA, Hubbell FA. Predicting risk of breast cancer in postmenopausal women by hormone receptor status. J Natl Cancer Inst 2007; 99: 1695-1705.

5. Cicek M, Iwaniec UT, Goblirsch MJ, Vrabel A, Ruan M, Clohisy DR, Turner RR, Oursler MJ. 2-methoxyestradiol suppresses osteolytic breast cancer tumor progression in vivo. Cancer Res 2007; 67: 10106-10111.

6. Curtis CD, Likhite VS, McLeod IX, Yates JR, Nardulli AM. Interaction of the tumor metastasis suppressor nonmetastatic protein 23 homologue $\mathrm{h} 1$ and estrogen receptor $\alpha$ alters estrogen-responsive gene expression. Cancer Res 2007; 67: 10600-10607.

7. Datta S, Hoenerhoff MJ, Bommi P, Sainger R, Guo WP, Dimri M, Band H, Band V, Green JE, Dimri GP. Bmi-1 cooperates with $\mathrm{H}$-ras to transform human mammary epithelial cells via Dysregulation of multiple growth-regulatory pathways. Cancer Res 2007; 67: 10286-10295.

8. Decock J, Ji-Rong L, Laxton RC, Shu XO, Hodgkinson C, Hendrickx W, Pearce EG,

BCO/670/2008/JW
Gao YT, Pereira AC, Paridaens R, Zheng W, Ye S. Association of matrix metalloproteinase-8 gene variation with breast cancer prognosis. Cancer Res 2007; 67: 10214-10221.

9. Dowling RJO, Zakikhani M, Fantus IG, Pollak $M$, Sonenberg N. Metformin inhibits mammalian target of rapamycin-dependent translation initiation in breast cancer cells. Cancer Res 2007; 67: 10804-10812.

10. Easton DF, Deffenbaugh AM, Pruss D, Frye C, Wenstrup RJ, Allen-Brady K, Tavtigian SV, Monteiro ANA, Iversen ES, Couch FJ, Goldgar $D E$. A systematic genetic assessment of 1,433 sequence variants of unknown clinical significance in the BRCA1 and BRCA2 breast cancer-predisposition genes. Am J Hum Genet 2007; 81: 873-883.

11. Eilon T, Groner B, Barash I. Tumors caused by overexpression and forced activation of Stat5 in mammary epithelial cells of transgenic mice are parity-dependent and developed in aged, postestropausal females. Int J Cancer 2007; 121: 1892-1902.

12. Einbond LS, Sue T, Wu HA, Friedman R, Wang XM, Ramirez A, Kronenberg F, Weinstein IB. The growth inhibitory effect of actein on human breast cancer cells is associated with activation of stress response pathways. Int J Cancer 2007; 121: 2073-2083.

13. Finn RS, Dering J, Ginther C, Wilson CA, Glaspy P, Tchekmedyian N, Slamon DJ. Dasatinib, an orally active small molecule inhibitor of both the src and abl kinases, selectively inhibits growth of basal-type/"triple-negative" breast cancer cell lines growing in vitro. Breast Cancer Res Treat 2007; 105: 319-326.

14. Gill JK, Maskarinec G, Wilkens LR, Pike MC, Henderson BE, Kolonel LN. Nonsteroidal antiinflammatory drugs and breast cancer risk the multiethnic cohort. Am J Epidemiol 2007; 166: 1150-1158.

15. Ginestier C, Adelaide J, Goncalves A, Repellini L, Sircoulomb F, Letessier A, Finetti P, Geneix J, Charafe-Jauffret E, Bertucci F, Jacquemier J, Viens P, Birnbaum D. ERBB2 phosphorylation 
and trastuzumab sensitivity of breast cancer cell lines. Oncogene 2007; 26: 7163-7169.

16. Harrell JC, Dye WW, Harvell DME, Pinto M, Jedlicka P, Sartorius CA, Horwitz KB. Estrogen insensitivity in a model of estrogen receptorpositive breast cancer lymph node metastasis. Cancer Res 2007; 67: 10582-10591.

17. Harris L, Fritsche $H$, Mennel R, Norton L, Ravdin P, Taube S, Somerfield MR, Hayes DF, Bast RC. American society of clinical oncology 2007 update of recommendations for the use of tumor markers in breast cancer. J Clin Oncol 2007; 25: 5287-5312.

18. Hosey AM, Gorski JJ, Murray MM, Quinn JE, Chung WY, Stewart GE, James CR, Farragher SM, Mulligan JM, Scott AN, Dervan PA, Johnston PG, Couch FJ, Daly PA, Kay E, McCann A, Mullan PB, Harkin DP. Molecular basis for estrogen receptor $\alpha$ deficiency in BRCA1-linked breast cancer. J Natl Cancer Inst 2007; 99: 1683-1694.

19. Ignatiadis $M$, Xenidis N, Perraki M, Apostolaki S, Politaki E, Kafousi M, Stathopoulos EN, Stathopoulou A, Lianidou E, Chlouverakis G, Sotiriou C, Georgoulias V, Mavroudis D. Different prognostic value of cytokeratin-19 mRNApositive circulating tumor cells according to estrogen receptor and HER2 status in earlystage breast cancer. J Clin Oncol 2007; 25: 5194-5202.

20. Mertens-Talcott SU, Chintharlapalli S, Li MR, Safe S. The oncogenic microRNA-27a targets genes that regulate specificity protein transcription factors and the G(2)-M checkpoint in MDA-MB-231 breast cancer cells. Cancer Res 2007; 67: 11001-11011.

21. Meslin F, Hamai A, Gao P, Jalil A, Cahuzac N, Chouaib S, Mehrpour M. Silencing of prion protein sensitizes breast adriamycin-resistant carcinoma cells to TRAIL-mediated cell death. Cancer Res 2007; 67: 10910-10919.

22. Naughton C, MacLeod K, Kuske B, Clarke R, Cameron DA, Langdon SP. Progressive loss of estrogen receptor $\alpha$ cofactor recruitment in endocrine resistance. Mol Endocrinol 2007; 21: 2615-2626.

23. Pujana MA, Han JDJ, Starita LM, Stevens KN, Tewari M, Ahn JS, Rennert G, Moreno V, Kirchhoff T, Gold B, Assmann V, ElShamy WM, Rual JF, Levine D, Rozek LS, Gelman RS, Gunsalus KC, Greenberg RA, Sobhian B,
Bertin N, Venkatesan K, Ayivi-Guedehoussou N, Sole X, Hernandez P, Lazaro C, Nathanson KL, Weber BL, Cusick ME, Hill DE, Offit K, Livingston DM, Gruber SB, Parvin JD, Vidal M. Network modeling links breast cancer susceptibility and centrosome dysfunction. Nat Genet 2007; 39: 1338-1349.

24. Roarty K, Serra R. Wnt5a is required for proper mammary gland development and TGF- $\beta$-mediated inhibition of ductal growth. Development 2007; 134: 3929-3939.

25. Schroth W, Antoniadou L, Fritz P, Schwab M, Muerdter T, Zanger UM, Simon W, Eichelbaum $\mathrm{M}$, Brauch $\mathrm{H}$. Breast cancer treatment outcome with adjuvant tamoxifen relative to patient CYP2D6 and CYP2C19 genotypes. J Clin Oncol 2007; 25: 5187-5193.

26. Schunke D, Span P, Ronneburg H, Dittmer A, Vetter M, Holzhausen HJ, Kantelhardt E, Krenkel S, Mueller V, Sweep F, Thomssen C, Dittmer J. Cyclooxygenase-2 is a target gene of rho GDP dissociation inhibitor $\beta$ in breast cancer cells. Cancer Res 2007; 67: 10694-10702.

27. Umanskaya $\mathrm{K}$, Radke $\mathrm{S}$, Chander $\mathrm{H}$, Monardo R, Xu X, Pan ZQ, O'Connell MJ, Germain D. Skp2B stimulates mammary gland development by inhibiting REA, the repressor of the estrogen receptor. Mol Cell Biol 2007; 27: 7615-7622.

28. Wang Z, Dahiya S, Provencher H, Muir B, Carney E, Coser K, Shioda T, Ma XJ, Sgroi DC. The prognostic biomarkers HOXB13, IL17BR, and $\mathrm{CHDH}$ are regulated by estrogen in breast cancer. Clin Cancer Res 2007; 13: 6327-6334.

29. Wienke D, Davies GC, Johnson DA, Sturge J, Lambros MBK, Savage K, Elsheikh SE, Green AR, Ellis IO, Robertson D, Reis-Filho JS, Isacke CM. The collagen receptor endo180 (CD280) is expressed on basal-like breast tumor cells and promotes tumor growth in vivo. Cancer Res 2007; 67: 10230-10240.

30. Yang XR, Pfeiffer RM, Garcia-Closas M, Rimm DL, Lissowska J, Brinton LA, Peplonska B, Hewitt SM, Cartun RW, Mandich D, Sasano H, Evans DB, Sutter TR, Sherman ME. Hormonal markers in breast cancer: Coexpression, relationship with pathologic characteristics, and risk factor associations in a population-based study. Cancer Res 2007; 67: 10608-10617. 